\title{
The Role of Bonding, Bridging and Linking: Aspects of Social Capital in Mental Health of Bosnian Refugees in the U.S.
}

\author{
Huaibo Xin ${ }^{1, *}$, Ajlina Karamehic-Muratovic ${ }^{2}$ \\ ${ }^{1}$ Department of Applied Health, School of Education, Health \& Human Behavior, Southern Illinois University Edwardsville, \\ Illinois, USA \\ ${ }^{2}$ Department of Sociology and Anthropology, College of Arts and Sciences, Saint Louis University, Missouri, USA
}

Received August 25, 2021; Revised September 17, 2021; Accepted November 11, 2021

\section{Cite This Paper in the following Citation Styles}

(a): [1] Huaibo Xin, Ajlina Karamehic-Muratovic, "The Role of Bonding, Bridging and Linking: Aspects of Social Capital in Mental Health of Bosnian Refugees in the U.S.," Universal Journal of Public Health, Vol. 9, No. 6, pp. 418 430, 2021. DOI: 10.13189/ujph.2021.090609.

(b): Huaibo Xin, Ajlina Karamehic-Muratovic (2021). The Role of Bonding, Bridging and Linking: Aspects of Social Capital in Mental Health of Bosnian Refugees in the U.S.. Universal Journal of Public Health, 9(6), 418 - 430. DOI: 10.13189/ujph.2021.090609.

Copyright $\odot 2021$ by authors, all rights reserved. Authors agree that this article remains permanently open access under the terms of the Creative Commons Attribution License 4.0 International License

\begin{abstract}
This study explored the role of bonding, bridging, and linking aspects of social capital among Bosnian refugees in the U.S. and their impact on the community's mental health. Using snowball sampling and criterion sampling, a total of 74 Bosnian refugees resettled in the U.S. participated in a cross-sectional study and responded to the modified online Personal Social Capital Scale. Most of the participants resided in Missouri, Illinois, New York, Georgia, Florida, California, and Virginia. They reported modest levels of bonding, bridging, and linking social capital; Married participants had higher levels of both bonding and bridging social capital than single, divorced, and widowed participants $(\mathrm{p}=0.036$; 0.013 ); religious neutral/not religious participants had a higher level of bridging social capital $(\mathrm{p}=0.018)$ than religious/very religious participants; males had a higher level of linking social capital than females $(p=0.047)$. Age and the number of years living in the U. S. also made significant differences in participants' social capital. Bonding and overall social capital were significantly associated with participants' mental health, although the relationships did not appear to be strong. Multi-level social capital building interventions/approaches tailored to Bosnian refugees are recommended, and their long-term mental health effects should be further examined.
\end{abstract}

Keywords Bonding, Bridging, Linking Social Capital,
Mental Health, Refugees

\section{Introduction}

As social capital received increasing attention in sociological research, in a meta-analysis of journal article definitions of social capital between 1988 and 2006, at least six common definitions were identified [1]. The most commonly used social capital definitions focus on network, resources, relationships, trust, reciprocity, norms, civic engagement, and community cohesion [1, 2]. Putman's early definition of social capital focused on three different types of network resources including bonding, bridging, and linking social capital [2, 3]. Bonding social capital "describes connections within a group or community characterized by high levels of similarity in demographic characteristics, attitudes, and available information and resources" [4]. Bridging social capital "describes connections that link people across a cleavage that typically divides society (such as race, or class, or religion) and bridges among communities, groups, or organizations" [4]. Linking social capital "describes norms of respect and networks of trusting relationships between people who are interacting across explicit, formal or institutionalized 
power or authority gradients in society" [4, 5]. Both physical and mental health benefits of bonding, bridging, and linking social capital have been well documented by researchers in social, behavioral, and health sciences [as cited in 6].

The favorable effect of social networking, one of the social capital concepts, on human mental wellbeing has been historically demonstrated and documented [7] For example, Bryant and his colleagues explored the relationship between social network structure and the onset of PTSD and depression after a disaster [8]. A community-based cohort study was conducted with 558 survivors of a major bushfire disaster in Australia. Participants' social connections were measured, and a social network map was constructed. Results illustrated that participants with more social connections that they trusted and could depend on led to a lower risk of suffering from PTSD and depression [8]. Similarly, in Switzerland, college students were under lockdown during COVID-19 pandemic and therefore it limited social networking, presented higher levels of psychological symptoms including stress anxiety, loneliness and depression, and more isolation in their social network, less social interaction and emotional support, and more physical isolation. The study highly recommended that universities and researchers should consider students' social contacts in improving their mental health during/after a disease outbreak [9]. A similar relationship between social network and mental health was discovered among people lived in heavily affected conflict areas in another study. A total of 1,239 participants aged 16 years or above from post-conflict area in Kosovo reported their social network depth using the frequency of contacting their familiar and unfamiliar people and their symptoms of depression and anxiety using a clinical scale. Frequent contacts alleviated the symptoms of both participants' depression and anxiety [10]. Findings regarding social networking and mental health remained consistent across many other studies among military personnel, lesbian, gay, bisexual, and transgender older adults, pregnant women, farmers, and others [11-14]. In addition, research showed that social networking increased mental health patients' access to psychiatric care while a supportive social network could also be a substitute for professional mental healthcare services [15-18].

Community cohesion, another concept of social capital, has also proven to be effective in promoting mental health and reducing the severity of mental health issues, including studies examining relationships between neighborhood social cohesion and mental health of a multi-ethnic population with atherosclerosis [19]; the longitudinal effect of neighborhood social cohesion on mental health disparities [20]; the effect of perceived community cohesion on youth mental stress [21]; and the effect of perceived community cohesion on Post-Traumatic Stress Disorder (PTSD) symptoms among low-income African Americans [22]. About two and a half years after the earthquake and tsunami in Japan in 2011, a follow-up survey was conducted among 3,567 adult survivors aged 65 and older from the affected area. Community social cohesion was measured by residents' perceptions of trust in the community, level of mutual help, and community attachment. Compared to the baseline data from the same population before the disaster, seniors who had a higher level of pre-disaster community cohesion were at a lower risk of PTSD, and community cohesion strengthened community resilience to natural disasters [23]. Using mixed methods and through three British national cohort studies, quantitative data were obtained from 10,312 participants over 50, with 230 of them completing a qualitative interview. Neighborhood cohesion was assessed by sense of community and attraction to neighborhood using an 18-item Neighborhood Cohesion Scale. Greater community cohesion predicted better mental outcomes among study participants, and it presented a stronger impact on older participants' mental wellbeing [24]. Similarly, 3,098 Hispanic and non-Hispanic adult residents from 597 neighborhoods in metropolitan Phoenix reported a significant positive association between neighborhood social cohesion and both physical and psychological health [25]. The role of social cohesion was further emphasized to address COVID-19 impact on marginalized communities' mental health. It suggested that fostering community cohesion through building trust, enhancing social interaction, promoting a sense of bonding, and cultivating a sense of identity improved community's psychological wellbeing [26].

Mental health issues have been much more predominant and severe among refugee populations worldwide than they are among the general population. A most recent critical review of prevalence, predictors, and integrated care of refugees and torture survivors' mental health indicated that in the past 10 years, a large number of refugees had been torture survivors who did not normally receive mental health screening during an initial physical examination for refugees, and the prevalence rate of clinically diagnosed PTSD, depression, and anxiety among these torture survivors could be as high as more than $90 \%$ [27]. "Torture severity, post-migration difficulties, and wait time to receive clinical services" were major predictors of the occurrence of refugees' mental health symptoms [27]. Bogic et al. systematically reviewed the long-term mental health of adult war-refugees after 5 or more years of their resettlement and found that mental disorders remained significant among these war-refugees as a result of both pre-migration war traumas and post-migration socio-economic factors [28]. Income, housing, employment, language skills and interpretation, social support and social isolation, and discrimination were the major post-migration indicators of refugees' long-term mental health, and there was a lack of evidence illustrating the effectiveness of refugee mental health interventions [29]. During the recent COVID-19 pandemic, Júnior et al. described that refugees were experiencing the crisis within 
the crisis which further deteriorated their mental health. Factors including "overcrowding, disruption of sewage disposal, poor standards of hygiene, poor nutrition, negligible sanitation, lack of access to shelter, health care, public services, and safety" led to the aggravated fear of getting both mental illness and COVID-19 infection [30]. The COVID-19 pandemic itself also presented unprecedented challenges and took a tremendous toll on global populations' psychological wellbeing, and refugees were among the most vulnerable [31-33]. The current study examines bonding, bridging, and linking aspects of social capital among U.S. Bosnian refugees and their associations with their mental health. A study was conducted in 2019 to examine the long-term psychological distress of Bosnian war survivors after they were being follow-up for 11 years. Not surprisingly, the levels of psychological distress remained high due to pre-, during, and post war traumas [34].

\section{Materials and Methods}

\subsection{Subjects}

A total of 74 Bosnian refugees resettled in the U.S. participated in this cross-sectional survey study. The participants were recruited using criterion and snowball sampling. Criterion sampling included identifying networks, organizations, and individuals who could identify and/or serve as multiple starting points for sampling individuals who i) were aged 18 and above and ii) arrived to the U.S. as refugees and/or whose parents arrived to the US as refugees from Bosnia. The participants were then recruited through a snowball sampling approach with these multiple starting points so as to avoid a homogenous sample. Sampling starting points included several local and national Bosnian organizations, community centers and/or religious establishments, social media networks unique to Bosnians in the U.S., and the Consulate General of Bosnia and Herzegovina in the U.S. No incentives were provided for participation. An anonymous Qualtrics survey link was emailed to potential participants aged 18 and above where the purpose of the study was briefly explained. All participants had to agree to participate in the study, thus providing informed consent. The questionnaire was made available in both English and Bosnian language.

\subsection{Measures}

Chen et al. (2009) developed a Personal Social Capital Scale for health and behavioral research. The Scale consists of 10 items (Cap1- Cap10) including 2 subscales and 42 subitems measured on a five-point Likert scale with $1=$ none or a few to $5=$ all or a lot. Bonding social capital was measured by the summation of five items from Cap1 through Cap5; bridging social capital was measured by the summation of five items from Cap6 through Cap10; the summation of both bonding and bridging social capital yielded an individual's total social capital score. The concepts of social capital including social network sizes, possessed resources, frequency of connections, trustworthy, reciprocity and social cohesion were addressed by the instrument. Both reliability and validity were tested using Cronbach alphas, confirmatory factor analysis, construct validity, and predictive validity. The estimated Cronbach alphas were 0.87 for the overall scale for social capital, 0.85 for the bonding capital subscale, and 0.84 for the bridging capital subscale [35]. The English version of the Personal Social Capital Scale was adopted and made culturally appropriate for the current study population (Appendix A). The permission of the use of this Personal Social Capital Scale was obtained from the corresponding author (Dr. Chen) prior to the study. Specifically, the modifications were tailored to Bosnian refugees' social connections/activities with religious groups and cultural groups, as well as their linking social capital.

Linking social capital Cap11 through Cap15 was added as the 3rd subscale with 21 subitems on a five-point Likert scale consistent with the 1st and 2 nd subscales to assess "the norms of respect and networks of trusting relationships between people who are interacting across explicit, formal or institutionalized power or authority gradients in society" $[4,5]$.The summation of Cap11 through Cap15 yielded an individual Bosnian refugee participant's linking social capital, and the summation of Cap1 through Cap15 yield a Bosnian refugee's total social capital. The additions brought the total number of subitems included in this modified Personal Social Capital Scale to 75 which constituted three subscales. Data on participants' demographics, levels of English proficiency and Religiosity, and overall mental health were also collected. For instance, participants were asked to rate their overall health and mental health from very good, good, fair to poor. The second author of this study who is a native Bosnian translated the original scale used for the study and ensured it was culturally appropriate.

\subsection{Procedure}

This study was approved by the University's Institutional Review Board. Information on variables related to participants' bonding, bridging, and linking social capital, and their mental health outcome was collected through an anonymous Qualtrics survey sent to the participants' email addresses between January and March 2021. Before they started the survey, participants were informed that the study was anonymous and voluntary. They were also informed of study risks and benefits. The purpose of the study and an informed consent were included at the beginning of the online survey. On average, participants spent 15 to 20 minutes on completing the survey. Data were entered into an SPSS 24.0 database 
through Qualtrics.

\subsection{Analysis}

SPSS 24.0 (IBM) was used to analyze the quantitative data. Descriptive statistics (e.g., means, frequencies, and summations) were applied to each item Cap1 though Cap15 as well as each subscale and the modified Personal Social Capital Scale. Means of each item Cap1 and Cap15 and subscale, and the overall scale were compared using independent samples t-test and One-way Analysis of Variance (ANOVA) followed by Tukey HSD post hoc comparisons (p value at 0.05 , one-tailed) by participants' age, gender, marital status, education, income, occupation, residential area, English proficiency, religiosity, and use of social media. The relationships between participants' bonding, bridging, linking, and overall social capital, and their self-reported levels of mental health status and overall health were examined by Pearson correlation.

\section{Results}

Table 1 displays the study participants' demographics. A total of 74 Bosnian refugees in the U.S. responded to the survey. More than half of them lived in Missouri, Illinois, and New York with the rest living in states such as Georgia, Florida, California, and Virginia at the time of the study being conducted. Approximately, 55\% of the participants had been resettled in the U.S. for 21 years or more. Among all participants, about 53\% of them were male. The largest age group in the study was 46 years old and above (32.4\%), and the respondents were predominantly married (64.9\%). About $57 \%$ of the respondents reported earning a Bachelor or post-Bachelor's degree including a master's, professional, or doctorate degree. One third of the participants' households earned an annual income of $\$ 100,000$ or more. Participants' occupations varied from academic researcher, banker, marketing director, pharmacist, dentist, medical assistant, building manager, information technician, engineer, realtor, and sales representative to social worker. Among 62 participants who responded to the survey 56 stated that English was not their first language, and 41 stated that their English proficiency level was advanced. More than half of the participants indicated that they were religious or very religious. In addition, 56 out of 62 participants reported that they used social media (e.g., Facebook, Skype, etc.) to stay connected with other Bosnians in the U.S. as well as outside of U.S.

The summations of each item, each subscale, and the overall scale were calculated. Items from Cap1 to Cap5 in subscale 1 examined the participants' bonding social capital. Less than $50 \%$ of the participants rated the number of people they knew including their neighbors, co-workers, community leaders, service providers, mosque members/leaders, and country fellows/current/old classmates) either more than average or a lot while more than $50 \%$ of them rated more than average or a lot for immediate family members, relatives, and friends; more than $50 \%$ of the participants only kept routine contacts with more than an average number of their immediate family members and friends who they also trust the most; more than $50 \%$ of the participants only believed more than an average number of their immediate family members, relatives, and friends would definitely help them upon their request; except for high school or more education and a professional job, less than $50 \%$ of the participants believed that more than an average number of people they knew possessed political power, wealth or owners of an enterprise or a company, broad connections with others, and high reputation/influential. Items from Cap6 to Cap10 in subscale 2 examined the participants' bridging social capital. More than $50 \%$ of the participants rated average and below when they were asked about the number of the American/non-Bosnian political, economic, social, cultural, and recreational and leisure groups/organizations in their local community; their involvement in these groups/organizations; these groups/organizations' representation of Bosnian refugees' rights and interests; these groups/organizations' response to Bosnian refugees' call for help; and these groups/organizations' possession of power for decision-making, financial assets, broad social connections, and great social influence while compared to other ratings, average and a few are the most frequent ratings chosen by the participants. Items from Cap11 to Cap15 in subscale 3 examined the participants' linking social capital. More than $50 \%$ of the participants rated average and below when they were asked about the number of local, state, national and/or international governmental and non-governmental agencies, recreational networks, and networks for professional advocacy, interest groups, religious organizations, and political mobilizations they knew outside of their local community; their access to these, these agencies / organizations / networks' representation of Bosnian refugees' rights and interest; these agencies / organizations / networks' response to Bosnian refugees' call for help; these agencies/organizations/networks' possession of significant power for decision-making, financial resources, diverse services, broad social connections and great social influence while compared to other ratings, average is the most frequent rating. 
Table 1. Demographics of Study Participants $(\mathrm{N}=74)$

\begin{tabular}{|c|c|}
\hline Demographics & Number (Percentage) \\
\hline \multicolumn{2}{|l|}{ Gender } \\
\hline Male & $39(52.7)$ \\
\hline Female & $23(31.1)$ \\
\hline Not responded & $12(16.2)$ \\
\hline \multicolumn{2}{|l|}{ Age } \\
\hline $22-35$ & $21(28.4)$ \\
\hline $36-45$ & $11(14.9)$ \\
\hline $46-74$ & $24(32.4)$ \\
\hline Not responded & $18(24.3)$ \\
\hline \multicolumn{2}{|l|}{ Marital Status } \\
\hline Married & $48(64.9)$ \\
\hline Single & $10(13.5)$ \\
\hline Divorced & $3(4.1)$ \\
\hline Widowed & $1(1.4)$ \\
\hline Not responded & $12(16.2)$ \\
\hline \multicolumn{2}{|l|}{ Degree Completed } \\
\hline Pre-Bachelor & $20(27.0)$ \\
\hline Bachelor & $25(33.8)$ \\
\hline Post-Bachelor & $17(23.0)$ \\
\hline Not responded & $12(16.2)$ \\
\hline \multicolumn{2}{|l|}{ Household Income } \\
\hline$\$ 59,999$ and below & $13(17.6)$ \\
\hline$\$ 60,000$ and $\$ 99,000$ & $20(27.0)$ \\
\hline$\$ 100,000$ and above & $24(32.4)$ \\
\hline Not responded & $17(23.0)$ \\
\hline \multicolumn{2}{|l|}{ Residential State } \\
\hline Arizona & $1(1.3)$ \\
\hline California & $3(4.1)$ \\
\hline Connecticut & $1(1.3)$ \\
\hline Florida & $3(4.1)$ \\
\hline Georgia & $4(5.4)$ \\
\hline Illinois & $9(12.2)$ \\
\hline Kentucky & $1(1.3)$ \\
\hline Michigan & $1(1.3)$ \\
\hline Missouri & $23(31.1)$ \\
\hline New Jersey & $1(1.3)$ \\
\hline New York & $6(8.1)$ \\
\hline North Dakota & $1(1.3)$ \\
\hline Pennsylvania & $1(1.3)$ \\
\hline Texas & $1(1.3)$ \\
\hline Virginia & $2(2.7)$ \\
\hline Not responded & $16(21.6)$ \\
\hline \multicolumn{2}{|l|}{ Years in US } \\
\hline 20 years or less & $19(25.7)$ \\
\hline 21 to 25 years & $32(43.2)$ \\
\hline 26 year or more & $9(12.2)$ \\
\hline Not responded & $14(18.9)$ \\
\hline \multicolumn{2}{|c|}{ English as First Language } \\
\hline Yes & $6(8.1)$ \\
\hline No & $56(75.7)$ \\
\hline Not responded & $12(16.2)$ \\
\hline \multicolumn{2}{|l|}{ English Proficiency } \\
\hline Beginner & $0(0)$ \\
\hline Intermediate & $21(28.4)$ \\
\hline Advanced & $41(55.4)$ \\
\hline Not responded & $12(16.2)$ \\
\hline \multicolumn{2}{|l|}{ Religiosity } \\
\hline Not Religious & $6(8.1)$ \\
\hline Neutral & $18(24.3)$ \\
\hline Religious & $33(44.6)$ \\
\hline Very Religious & $5(6.8)$ \\
\hline Not responded & $12(21.6)$ \\
\hline
\end{tabular}


Independent samples t-tests comparing differences in bonding, bridging, linking, and overall social capital by gender, marital status, English proficiency, and religiosity, respectively were conducted. Married participants presented higher levels of both bonding and bridging social capital than single, divorced, and widowed participants $(\mathrm{p}=0.036 ; 0.013) ;$ compared to religious/very religious participants, religious neutral/not religious participants had a higher level of bridging social capital $(p=0.018)$; males had a higher level of linking social capital than females $(p=0.047)$; overall, married individuals had more social capital than the rest $(\mathrm{p}=$ 0.046). No significant differences in bonding, bridging, linking, and overall social capital were identified between intermediate and advanced English language proficiency groups.

Results also demonstrated the differences in bonding, bridging, linking, and overall social capital by age and number of years resettled in the U.S. Significant differences in bonding, bridging, and overall social capital were identified among different age groups $(\mathrm{F}=8.4, \mathrm{p}=$ $0.001 ; \mathrm{F}=3.3, \mathrm{p}=0.043 ; \mathrm{F}=4.1, \mathrm{p}=0.024)$; both age groups between 36 and 45 years old and between 46 and 74 presented a higher bonding social capital than these between 22 and 35 years old $(p=0.003 ; p=0.006)$; the age group between 46 and 74 also presented a higher overall social capital than these between 22 and 35 years old $(p=0.047)$. In addition, the number of years living in the US also differentiated the levels of bonding and overall social capital $(\mathrm{F}=7.7, \mathrm{p}=0.001 ; \mathrm{F}=6.6, \mathrm{p}=$ 0.003 ); compared to the participants living in the US between 21 and 25 years, participants resided in the U.S. for 20 years or less or 26 years or above, both groups, reported a higher level of bonding social capital $(\mathrm{p}=$ $0.013 ; \mathrm{p}=0.004)$ and a higher level of overall social capital $(\mathrm{p}=0.018 ; \mathrm{p}=0.010)$. Both household income and degree awarded did not make any significant differences in bonding, bridging, linking, and overall social capital in the current study.

The relationships between bonding, bridging, linking and overall social capital, and overall health and mental health were revealed. Bonding social capital was significantly related to participants' self-reported overall and mental health $(\mathrm{r}=0.290, \mathrm{p}=0.043 ; \mathrm{r}=0.453, \mathrm{p}=$ $0.001)$. The overall social capital was significantly related to participants' mental health $(\mathrm{r}=0.301, \mathrm{p}=0.045)$ while the relationship did not appear to be strong.

\section{Discussion}

The current study included a national sample of 74 Bosnian refugee participants resettled in the U.S. and employed in a variety of fields, with the majority of the participants reporting intermediate or advanced English language proficiency. Although participants reported a strong bond with most of their nuclear and extended family members and friends who they trust and depend on, they also expressed less connections with/confidence in their neighbors, co-workers, community leaders, service providers, mosque members/leaders, and country fellows/current/old classmates. They did not perceive that people they knew had much political power, money, and high societal influence, or that they were widely socially connected. Both bridging and linking social capital aspects were not strongly present among the participants, although compared to their unmarried and more religious counterparts, married and less religious Bosnians appeared to have more bridging social capital, and males had more linking social capital. Most participants also reported a low/very low involvement in non-Bosnian groups/organizations for political, economic, social, cultural, and recreational and leisure purposes within their local community in the U.S. and were not linked with governmental/non-governmental agencies and networks for professional advocacy, religion, and political mobilization outside of their community either. The challenges of widening and strengthening social capital among resettled refugees, suggested by the existing literature, may explain the Bosnians' weak bridging and linking social capital after being resettled in the U.S., such as unfamiliarity of U.S. culture, value, custom, norm, law, and system, worry of being judged, and discriminated due to differences in ethnicity, religion, education,; gender inequities; inadequate access to information and services; low self-esteem; shame of asking for help [6].

Approaches to expanding/enhancing individual and community's social capital have been well developed and proven to be effective among general and refugee populations. So as to address Bosnian refugees' mental health through social capital building, some of the organizational and community level approaches could be modified for Bosnian refugees to increase both their bridging and linking social capital. For example, Cai implemented a study using photovoice community participatory approach to have three socioeconomically disadvantaged communities in Republic of the Philippines explore their bonding, bridging, and linking social capital through visual narratives, unstructured observations, and semi-structured interviews, and learn how social capital could significantly contribute to their community's disaster resilience and facilitate their disaster preparedness, response, and recovery [36]. Similarly, Terrion introduced a school-based intervention using Families and Schools Together model to build social capital for vulnerable families. Families who have children with an academic risk were partnered with a program facilitator, a substance abuse counselor, a school professional, one or two parent partners, and a clinical social worker, and together with their children participated in structured program activities for social capital building, which resulted in a positive growth in family and child relationship; child's relationship with his/her family, friends, and adults outside the family; family relationship with the school; 
family access to community resources, family and child sense of empowerment, belonging, and confidence; and child behavioral change [37]. Kahne et al. also integrated civics courses into high school curriculum to build social capital for students' civic and political engagement, which significantly strengthened the students' norms of civic participation, social trust, and knowledge of social networks through a variety of curriculum activities, including role play, service learning, and exposure to role models/speakers [38]. Moreover, Brune and Bossert implemented a systematic methodologically based structured management and leadership intervention in two local post-conflict communities in Nicaragua. Both communities had low levels of social capital. The intervention aimed to strengthen community organization and members' self-management through developing individuals' management and leadership capacities. It also aimed to increase community members' engagement in community activities and trust among community members and between the community and local public institutions [39]. Through activities like leadership training workshops, community outreach, a community radio program to deliver information, education, and communication, value and leadership campaigns, compared to the members in the control community, there was a significant increase in intervention community members' participation in groups and social networks; sense of belonging and ownership; trust towards their neighbors; and civic participation and empowerment (e.g., participating in a protest, contacting local health officials about a local problem, and donating to a non-profit organization) [39]. Similarly, Roberts' research further demonstrated the relationship between leadership development and social capital building in a healthcare system [40].

In addition, social capital can also be fostered through community recreational events. For instance, as part of the Australia Africa 2006 Sports Development Program, the Active Community Clubs Initiative of the Australian Sports Commission focused on developing active and functional communities through the activities and strategies of local Active Community Clubs in South Africa. Community-based sports programs along with health programs and other events were delivered to local communities through five participating Active Community Clubs in the Eastern Cape Province [41]. Social capital was generated at both individual and community levels; participants gained access to physical resources and networks and experienced the sense of belonging and trust; it also successfully facilitated civic engagement such as volunteering [41]. Peachey et al. implemented the Street Soccer USA program in five US cities to build social capital among volunteer coaches and homeless people through a partnership between these two parties. The qualitative results suggested that the program activities increased the volunteer coaches' awareness and understanding of homeless individuals; built the sense of community between volunteers and the homeless players; and enhanced volunteers' passion and motivation to reaching out and working with philanthropy and the non-profit organizations in social justice [42]. Both studies concurred with Skinner et al.'s early research findings on social capital development in disadvantaged communities through sports. After a thorough review of sport programs/models that were adopted by countries like UK, Canada, and Australia, the researchers commented that sport had substantial social value which could provide disadvantaged individuals/communities with a supportive environment and encouragement of making external connections [43]. Bosnians are generally in favor of social events and social gatherings, and one of the popular recreational activities among Bosnians is soccer.

Moreover, in the current study, although the relationships did not seem strong, both bonding social capital and overall social capital were significantly related to participants' self-reported mental health. The results, unsurprisingly, concurred with previous research findings. A great number of studies have established the relationship between social capital including bonding social capital and mental health (e.g., major depression), and evidence-based interventions were developed to improve mental health through social capital building [e.g., as cited in 6, 44-48].

\section{Conclusions}

Overall, Bosnian refugees in this study demonstrated modest levels of bonding, bridging, and linking social capital. Bonding and overall social capital were significantly related to the participants' mental health. Promoting social capital can improve Bosnian refugees' mental health. The most recent systematic review of social capital building interventions in public health concluded that social capital interventions were feasible to reinforce social capital to influence health outcomes but multilevel social capital interventions for more prominent and sustainable, and broader changes were suggested and the benefits of social capital interventions among specific population groups should also be considered to be examined segmentally [49]. Moreover, the sustainability of the effect of social capital interventions on human mental health will benefit from a further exploration [50]. 


\section{Appendix A Modified Personal Social Capital Scale}

\section{Bonding Capital}

\begin{tabular}{|c|c|c|c|c|c|}
\hline $\begin{array}{l}\text { Cap1. How would you rate the number of people you know in each of } \\
\text { the following nine categories? }\end{array}$ & A lot & $\begin{array}{c}\text { More than } \\
\text { average }\end{array}$ & Average & $\begin{array}{l}\text { Less than } \\
\text { average }\end{array}$ & A few \\
\hline Your immediate family members & 5 & 4 & 3 & 2 & 1 \\
\hline Your relatives & 5 & 4 & 3 & 2 & 1 \\
\hline Your neighbors & 5 & 4 & 3 & 2 & 1 \\
\hline Your friends & 5 & 4 & 3 & 2 & 1 \\
\hline Your coworkers & 5 & 4 & 3 & 2 & 1 \\
\hline Your community leaders if any & 5 & 4 & 3 & 2 & 1 \\
\hline Your service providers (health service, etc.) & 5 & 4 & 3 & 2 & 1 \\
\hline Your mosque/church leaders/members if applicable & 5 & 4 & 3 & 2 & 1 \\
\hline Your country fellows/current/old classmates & 5 & 4 & 3 & 2 & 1 \\
\hline $\begin{array}{l}\text { Cap2. With how many people in each of the following nine categories } \\
\text { do you keep a routine contact? }\end{array}$ & A lot & $\begin{array}{c}\text { More than } \\
\text { average }\end{array}$ & Average & $\begin{array}{c}\text { Less than } \\
\text { average }\end{array}$ & A few \\
\hline Your immediate family members & 5 & 4 & 3 & 2 & 1 \\
\hline Your relatives & 5 & 4 & 3 & 2 & 1 \\
\hline Your neighbors & 5 & 4 & 3 & 2 & 1 \\
\hline Your friends & 5 & 4 & 3 & 2 & 1 \\
\hline Your coworkers & 5 & 4 & 3 & 2 & 1 \\
\hline Your community leaders if any & 5 & 4 & 3 & 2 & 1 \\
\hline Your service providers (health service, etc.) & 5 & 4 & 3 & 2 & 1 \\
\hline Your mosque/church leaders/members if applicable & 5 & 4 & 3 & 2 & 1 \\
\hline Your country fellows/current/old classmates & 5 & 4 & 3 & 2 & 1 \\
\hline $\begin{array}{l}\text { Cap3. Among the people in each of the following nine categories, how } \\
\text { many can you trust? }\end{array}$ & A lot & $\begin{array}{c}\text { More than } \\
\text { average }\end{array}$ & Average & $\begin{array}{c}\text { Less than } \\
\text { average }\end{array}$ & A few \\
\hline Your immediate family members & 5 & 4 & 3 & 2 & 1 \\
\hline Your relatives & 5 & 4 & 3 & 2 & 1 \\
\hline Your neighbors & 5 & 4 & 3 & 2 & 1 \\
\hline Your friends & 5 & 4 & 3 & 2 & 1 \\
\hline Your coworkers & 5 & 4 & 3 & 2 & 1 \\
\hline Your community leaders if any & 5 & 4 & 3 & 2 & 1 \\
\hline Your service providers (health service, etc.) & 5 & 4 & 3 & 2 & 1 \\
\hline Your mosque/church leaders/members if applicable & 5 & 4 & 3 & 2 & 1 \\
\hline Your country fellows/current/old classmates & 5 & 4 & 3 & 2 & 1 \\
\hline $\begin{array}{l}\text { Cap4. Among people in each of the following nine categories, how } \\
\text { many will definitely help you upon your request? }\end{array}$ & A lot & $\begin{array}{c}\text { More than } \\
\text { average }\end{array}$ & Average & $\begin{array}{c}\text { Less than } \\
\text { average }\end{array}$ & A few \\
\hline Your immediate family members & 5 & 4 & 3 & 2 & 1 \\
\hline Your relatives & 5 & 4 & 3 & 2 & 1 \\
\hline Your neighbors & 5 & 4 & 3 & 2 & 1 \\
\hline Your friends & 5 & 4 & 3 & 2 & 1 \\
\hline Your coworkers & 5 & 4 & 3 & 2 & 1 \\
\hline Your community leaders if any & 5 & 4 & 3 & 2 & 1 \\
\hline Your service providers (health service, etc.) & 5 & 4 & 3 & 2 & 1 \\
\hline Your mosque/church leaders/members if applicable & 5 & 4 & 3 & 2 & 1 \\
\hline Your country fellows/current/old classmates & 5 & 4 & 3 & 2 & 1 \\
\hline $\begin{array}{l}\text { Cap5. When people in all the nine categories (immediate family } \\
\text { members, relatives, neighbors, friends, coworkers, community } \\
\text { leaders, service providers, mosque/church leaders/members, and } \\
\text { country fellows/current/old classmates) are considered, how many } \\
\text { possess the following assets/resources? }\end{array}$ & A lot & $\begin{array}{l}\text { More than } \\
\text { average }\end{array}$ & Average & $\begin{array}{l}\text { Less than } \\
\text { average }\end{array}$ & A few \\
\hline Certain political power & 5 & 4 & 3 & 2 & 1 \\
\hline Wealth or owners of an enterprise or a company & 5 & 4 & 3 & 2 & 1 \\
\hline Broad connections with others & 5 & 4 & 3 & 2 & 1 \\
\hline High reputation/influential & 5 & 4 & 3 & 2 & 1 \\
\hline With high school or more education & 5 & 4 & 3 & 2 & 1 \\
\hline With a professional job & 5 & 4 & 3 & 2 & 1 \\
\hline
\end{tabular}




\section{Bridging Capital}

\begin{tabular}{|c|c|c|c|c|c|}
\hline $\begin{array}{l}\text { Cap6. How would you rate the number of the following two } \\
\text { types of American/non-Bosnian groups/organizations in your } \\
\text { local community? }\end{array}$ & A lot & $\begin{array}{c}\text { More than } \\
\text { average }\end{array}$ & Average & $\begin{array}{c}\text { Less than } \\
\text { average }\end{array}$ & A few \\
\hline $\begin{array}{l}\text { 1. Political, economic and social groups/organizations (political } \\
\text { parties, women's groups, seminars / workshops, boards / } \\
\text { committees, cooperate associations, alumni associations, } \\
\text { volunteer groups, etc.) }\end{array}$ & 5 & 4 & 3 & 2 & 1 \\
\hline $\begin{array}{l}\text { 2. Cultural, recreational and leisure groups/organizations } \\
\text { (religious groups, peer groups for cooking, sewing, clubs } \\
\text { including sport, music, dances, crafts, games, etc.) }\end{array}$ & 5 & 4 & 3 & 2 & 1 \\
\hline $\begin{array}{l}\text { Cap7. How many of each of these two types of } \\
\text { American/non-Bosnian groups and organizations in your } \\
\text { local community do you participate in? }\end{array}$ & A lot & $\begin{array}{c}\text { More than } \\
\text { average }\end{array}$ & Average & $\begin{array}{c}\text { Less than } \\
\text { average }\end{array}$ & A few \\
\hline $\begin{array}{l}\text { 1. Political, economic and social groups/organizations (political } \\
\text { parties, women's groups, seminars/workshops, } \\
\text { boards/committees, cooperate associations, alumni associations, } \\
\text { volunteer groups, etc.) }\end{array}$ & 5 & 4 & 3 & 2 & 1 \\
\hline $\begin{array}{l}\text { 2. Cultural, recreational and leisure groups/organizations } \\
\text { (religious groups, peer groups for cooking, sewing, clubs } \\
\text { including sport, music, dances, crafts, games, etc.) }\end{array}$ & 5 & 4 & 3 & 2 & 1 \\
\hline $\begin{array}{l}\text { Cap8. Among each of the two types of American/non-Bosnian } \\
\text { groups and organizations in your local community, how } \\
\text { many represent your rights and interests? }\end{array}$ & A lot & $\begin{array}{c}\text { More than } \\
\text { average }\end{array}$ & Average & $\begin{array}{c}\text { Less than } \\
\text { average }\end{array}$ & A few \\
\hline $\begin{array}{l}\text { 1. Political, economic and social groups/organizations (political } \\
\text { parties, women's groups, seminars/workshops, } \\
\text { boards/committees, cooperate associations, alumni associations, } \\
\text { volunteer groups, etc.) }\end{array}$ & 5 & 4 & 3 & 2 & 1 \\
\hline $\begin{array}{l}\text { 2. Cultural, recreational and leisure groups/organizations } \\
\text { (religious groups, peer groups for cooking, sewing, clubs } \\
\text { including sport, music, dances, crafts, games, etc.) }\end{array}$ & 5 & 4 & 3 & 2 & 1 \\
\hline $\begin{array}{l}\text { Cap9. Among each of the two types of American/non-Bosnian } \\
\text { groups and organizations in your local community, how } \\
\text { many will help you upon your request? }\end{array}$ & A lot & $\begin{array}{l}\text { More than } \\
\text { average }\end{array}$ & Average & $\begin{array}{c}\text { Less than } \\
\text { average }\end{array}$ & A few \\
\hline $\begin{array}{l}\text { 1. Political, economic and social groups/organizations (political } \\
\text { parties, women's groups, seminars/workshops, } \\
\text { boards/committees, cooperate associations, alumni associations, } \\
\text { volunteer groups, etc.) }\end{array}$ & 5 & 4 & 3 & 2 & 1 \\
\hline $\begin{array}{l}\text { 2. Cultural, recreational and leisure groups/organizations } \\
\text { (religious groups, peer groups for cooking, sewing, clubs } \\
\text { including sport, music, dances, crafts, games, etc.) }\end{array}$ & 5 & 4 & 3 & 2 & 1 \\
\hline $\begin{array}{l}\text { Cap10. When all groups and organizations in the two } \\
\text { categories below are considered, how many possess the } \\
\text { following assets/resources? } \\
\text { 1. Political, economic and social groups/organizations } \\
\text { (political parties, women's groups, seminars/workshops, } \\
\text { boards / committees, cooperate associations, alumni } \\
\text { associations, volunteer groups, etc.) } \\
\text { 2. Cultural, recreational and leisure groups/organizations } \\
\text { (religious groups, peer groups for cooking, sewing, clubs } \\
\text { including sport, music, dances, crafts, games, etc.) }\end{array}$ & A lot & $\begin{array}{c}\text { More than } \\
\text { average }\end{array}$ & Average & $\begin{array}{c}\text { Less than } \\
\text { average }\end{array}$ & A few \\
\hline Significant power for decision making & 5 & 4 & 3 & 2 & 1 \\
\hline Solid financial basis & 5 & 4 & 3 & 2 & 1 \\
\hline Broad social connections & 5 & 4 & 3 & 2 & 1 \\
\hline Great social influence & 5 & 4 & 3 & 2 & 1 \\
\hline
\end{tabular}




\section{Linking Capital}

\begin{tabular}{|c|c|c|c|c|c|}
\hline $\begin{array}{l}\text { Cap11. How would you rate the number of each of the following } \\
\text { outside of your local community? }\end{array}$ & A lot & $\begin{array}{c}\text { More than } \\
\text { average }\end{array}$ & Average & $\begin{array}{c}\text { Less than } \\
\text { average }\end{array}$ & $\begin{array}{c}\text { A } \\
\text { few }\end{array}$ \\
\hline $\begin{array}{l}\text { Local, state, federal, and/or international governmental agencies (social } \\
\text { welfare services, county health departments, United Nations, etc.) }\end{array}$ & 5 & 4 & 3 & 2 & 1 \\
\hline $\begin{array}{l}\text { Local, state, national, and/or international non-governmental organizations } \\
\text { (refugee resettlement agencies, foundations, associations, etc.) }\end{array}$ & 5 & 4 & 3 & 2 & 1 \\
\hline $\begin{array}{l}\text { Local, state, national and/or international recreational networks (sports, } \\
\text { etc.) }\end{array}$ & 5 & 4 & 3 & 2 & 1 \\
\hline $\begin{array}{l}\text { Local, state, national and/or international networks for professional } \\
\text { advocacy, interest groups, religious organizations, and political } \\
\text { mobilization }\end{array}$ & 5 & 4 & 3 & 2 & 1 \\
\hline Cap12. How many of the following do you have access to? & A lot & $\begin{array}{c}\text { More than } \\
\text { average }\end{array}$ & Average & $\begin{array}{c}\text { Less than } \\
\text { average }\end{array}$ & $\begin{array}{c}\text { A } \\
\text { few }\end{array}$ \\
\hline $\begin{array}{l}\text { Local, state, federal, and/or international governmental agencies (social } \\
\text { welfare services, county health departments, United Nations, etc.) }\end{array}$ & 5 & 4 & 3 & 2 & 1 \\
\hline $\begin{array}{l}\text { Local, state, national, and/or international non-governmental organizations } \\
\text { (refugee resettlement agencies, foundations, associations, etc.) }\end{array}$ & 5 & 4 & 3 & 2 & 1 \\
\hline $\begin{array}{l}\text { Local, state, national and/or international recreational networks (sports, } \\
\text { etc.) }\end{array}$ & 5 & 4 & 3 & 2 & 1 \\
\hline $\begin{array}{l}\text { Local, state, national and/or international networks for professional } \\
\text { advocacy, interest groups, religious organizations, and political } \\
\text { mobilization }\end{array}$ & 5 & 4 & 3 & 2 & 1 \\
\hline $\begin{array}{l}\text { Cap13. Among each of the following, how many represent your rights } \\
\text { and interests? }\end{array}$ & A lot & $\begin{array}{c}\text { More than } \\
\text { average }\end{array}$ & Average & $\begin{array}{c}\text { Less than } \\
\text { average }\end{array}$ & $\begin{array}{c}\text { A } \\
\text { few }\end{array}$ \\
\hline $\begin{array}{l}\text { Local, state, federal, and/or international governmental agencies (social } \\
\text { welfare services, county health departments, United Nations, etc.) }\end{array}$ & 5 & 4 & 3 & 2 & 1 \\
\hline $\begin{array}{l}\text { Local, state, national, and/or international non-governmental organizations } \\
\text { (refugee resettlement agencies, foundations, associations, etc.) }\end{array}$ & 5 & 4 & 3 & 2 & 1 \\
\hline $\begin{array}{l}\text { Local, state, national and/or international recreational networks (sports, } \\
\text { etc.) }\end{array}$ & 5 & 4 & 3 & 2 & 1 \\
\hline $\begin{array}{l}\text { Local, state, national and/or international networks for professional } \\
\text { advocacy, interest groups, religious organizations, and political } \\
\text { mobilization }\end{array}$ & 5 & 4 & 3 & 2 & 1 \\
\hline $\begin{array}{l}\text { Cap14. Among each of the following, how many will help you upon } \\
\text { your request? }\end{array}$ & A lot & $\begin{array}{c}\text { More than } \\
\text { average }\end{array}$ & Average & $\begin{array}{c}\text { Less than } \\
\text { average }\end{array}$ & $\begin{array}{c}\text { A } \\
\text { few }\end{array}$ \\
\hline $\begin{array}{l}\text { Local, state, federal, and/or international governmental agencies (social } \\
\text { welfare services, county health departments, United Nations, etc.) }\end{array}$ & 5 & 4 & 3 & 2 & 1 \\
\hline $\begin{array}{l}\text { Local, state, national, and/or international non-governmental organizations } \\
\text { (refugee resettlement agencies, foundations, associations, etc.) }\end{array}$ & 5 & 4 & 3 & 2 & 1 \\
\hline $\begin{array}{l}\text { Local, state, national and/or international recreational networks (sports, } \\
\text { etc.) }\end{array}$ & 5 & 4 & 3 & 2 & 1 \\
\hline $\begin{array}{l}\text { Local, state, national and/or international networks for professional } \\
\text { advocacy, interest groups, religious organizations, and political } \\
\text { mobilization }\end{array}$ & 5 & 4 & 3 & 2 & 1 \\
\hline $\begin{array}{l}\text { Cap15. When all four categories below are considered, how many } \\
\text { possess the following assets/resources? } \\
\text { 1. Local, state, federal, and/or international governmental agencies } \\
\text { (social welfare services, county health departments, United Nations, } \\
\text { etc.) } \\
\text { 2. Local, state, national, and/or international non-governmental } \\
\text { organizations (refugee resettlement agencies, foundations, } \\
\text { associations, etc.) } \\
\text { 3. Local, state, national and/or international recreational networks } \\
\text { (sports, etc.) } \\
\text { 4. Local, state, national and/or international networks for professional } \\
\text { advocacy, interest groups, religious organizations, and political } \\
\text { mobilization }\end{array}$ & A lot & $\begin{array}{c}\text { More than } \\
\text { average }\end{array}$ & Average & $\begin{array}{l}\text { Less than } \\
\text { average }\end{array}$ & $\begin{array}{c}\text { A } \\
\text { few }\end{array}$ \\
\hline Significant power for decision making & 5 & 4 & 3 & 2 & 1 \\
\hline Solid financial basis & 5 & 4 & 3 & 2 & 1 \\
\hline Diverse services & 5 & 4 & 3 & 2 & 1 \\
\hline Broad social connections & 5 & 4 & 3 & 2 & 1 \\
\hline Great social influence & 5 & 4 & 3 & 2 & 1 \\
\hline
\end{tabular}

Note: Personal Social Capital Scale was published by Chen et al. 2009 


\section{REFERENCES}

[1] G. M. Fulkerson, G. H. Thompson. (2008). The evolution of a contested concept: A meta - analysis of social capital definitions and trends (1988-2006), Sociological Inquiry, Vol. 78, No. 4, 536-557.https://onlinelibrary.wiley.com/do i/abs/10.1111/j.1475-682X.2008.00260.x

[2] R. R. Cottrell, J. T. Girvan, J. F. McKenzie, D. Seabert. (2018). Principles \& Foundations of Health Promotion and Education (7th ed). Pearson.

[3] R. D. Putman. (1995). Bowling alone: America's declining social capital, Journal of Democracy, Vol. 6, No. 1, 65-78. https://link.springer.com/chapter/10.1007/978-1-349-6296 5-7_12

[4] T. Claridge. (2018). Functions of social capital-bonding, bridging, linking. Social Capital Research, Vol. 20, 1-7. https://www.socialcapitalresearch.com/wp-content/uploads /2018/11/Functions-of-Social-Capital.pdf

[5] S. Szreter, M. Woolcock. (2004). Health by association? Social capital, social theory, and the political economy of public health, International Journal of Epidemiology, Vol. 33, No. 4, 650-67. https://academic.oup.com/ije/article/33/ $4 / 650 / 665431$ ?login=true

[6] H. Xin. (2018). Bonding, bridging, and linking: Social capital and its potential health impact among refugees in their resettlement countries, Universal Journal of Public Health, Vol. 6, No. 5, 231-239.https://www.hrpub.org/jour nals/article_info.php?aid=7337

[7] M. Greenblatt, R. M. Becerra, E. A. Serafetinides. (1982). Social networks and mental health: An overview, The American Journal of Psychiatry, Vol. 139, No. 8, 977-984. https://psycnet.apa.org/record/1982-30887-001

[8] R. A. Bryant, H. C. Gallagher, L. Gibbs, P. Pattison, C. MacDougall, L. Harms, ..., D. Lusher. (2017). Mental health and social networks after disaster, American Journal of Psychiatry, Vol. 174, No. 3, 277-285.https://ajp.psychia tryonline.org/doi/full/10.1176/appi.ajp.2016.15111403

[9] T. Elmer, K. Mepham, C. Stadtfeld. (2020). Students under lockdown: Comparisons of students' social networks and mental health before and during the COVID-19 crisis in Switzerland, Plos One, Vol. 15, No. 7, e0236337. https://journals.plos.org/plosone/article?id=10.1371/journa 1.pone. 0236337

[10] R. Nakayama, A. Koyanagi, A. Stickley, T. Kondo, S. Gilmour, A. Arenliu, K. Shibuya. (2014). Social networks and mental health in post-conflict Mitrovica, Kosova, BMC Public Health, Vol. 14, No. 1, 1-8. https://link.springer.co $\mathrm{m} /$ article/10.1186/1471-2458-14-1169

[11] A. B. Balaji, A. H. Claussen, D. C. Smith, S. N. Visser, M. J. Morales, R. Perou. (2007). Social support networks and maternal mental health and well-being, Journal of Women's Health, Vol. 16, No. 10, 1386-1396. https://www.liebertpu b.com/doi/abs/10.1089/jwh.2007.CDC10

[12] S. L. Hatch, S. B. Harvey, C. Dandeker, H. Burdett, N. Greenberg, N. T. Fear, S. Wessely. (2013). Life in and after the Armed Forces: Social networks and mental health in the UK military, Sociology of Health \& Illness, Vol. 35, No. 7, 1045-1064. https://onlinelibrary.wiley.com/doi/full/10.111 $1 / 1467-9566.12022$

[13] H. J. Kim, K. I. Fredriksen-Goldsen, A. E. Bryan, A. Muraco. (2017). Social network types and mental health among LGBT older adults, The Gerontologist, Vol. 57, No. suppl_1, S84-S94.https://academic.oup.com/gerontologist/ article/57/suppl_1/S84/2904645?login=true

[14] H. J. Stain, B. Kelly, T. J. Lewin, N. Higginbotham, J. R. Beard, F. Hourihan. (2008). Social networks and mental health among a farming population, Social Psychiatry and Psychiatric Epidemiology, Vol. 43, No. 10, 843-849. https://link.springer.com/article/10.1007/s00127-008-0374 $-5$

[15] M. Albert, T. Becker, P. Mccrone, G. Thornicroft. (1998) Social networks and mental health service utilisation-a literature review, International Journal of Social Psychiatry, Vol. 44, No. 4, 248-266. https://journals.sagepub.com/doi/ abs/10.1177/002076409804400402

[16] S. H. Kang, N. T. Wallace, J. K. Hyun, A. Morris, J. Coffman, J. R. Bloom. (2007). Social networks and their relationship to mental health service use and expenditures among Medicaid beneficiaries, Psychiatric Services, Vol. 58, No. 5, 689-695.https://ps.psychiatryonline.org/doi/full/ 10.1176/ps.2007.58.5.689

[17] R. E. Kogstad, E. Mönness, T. Sörensen. (2013). Social networks for mental health clients: Resources and solution, Community Mental Health Journal, Vol. 49, No. 1, 95-100. https://link.springer.com/article/10.1007/s10597-012-9491 $-4$

[18] P. K. Maulik, W. W. Eaton, C. P. Bradshaw. (2011). The effect of social networks and social support on mental health services use, following a life event, among the Baltimore Epidemiologic Catchment Area cohort, The Journal of Behavioral Health Services \& Research, Vol. 38 , No. 1, 29-50. https://link.springer.com/article/10.1007/s11 414-009-9205-z

[19] S. Echeverría, A. V. Diez-Roux, S. Shea, L. N. Borrell, S Jackson. (2008). Associations of neighborhood problems and neighborhood social cohesion with mental health and health behaviors: The Multi-Ethnic Study of Atherosclerosis, Health \& Place, Vol.14, No. 4, 853-865. https://www.sciencedirect.com/science/article/abs/pii/S135 3829208000105

[20] D. Fone, J. White, D. Farewell, M. Kelly, G. John, K. Lloyd, ..., F. Dunstan. (2014). Effect of neighbourhood deprivation and social cohesion on mental health inequality: A multilevel population-based longitudinal study, Psychological Medicine, Vol. 44, No. 11, 2449-2460. https://www.cambridge.org/core/journals/psychological-m edicine/article/abs/effect-of-neighbourhood-deprivation-an d-social-cohesion-on-mental-health-inequality-a-multilevel -populationbased-longitudinal-study/718B4A56CABD263 BAC6CC4779E934EE9

[21] T. Van Gundy, N. F. Stracuzzi, C. J. Rebellon, C. J. Tucker, E. S. Cohn. (2011). Perceived community cohesion and the stress process in youth, Rural Sociology, Vol. 76, No. 3, 293-318.https://onlinelibrary.wiley.com/doi/abs/10.1111/j. 1549-0831.2011.00050.x

[22] M. Gapen, D. Cross, K. Ortigo, A. Graham, E. Johnson, M. 
Evces, ..., B. Bradley. (2011). Perceived neighborhood disorder, community cohesion, and PTSD symptoms among low-income African Americans in an urban health setting, American Journal of Orthopsychiatry, Vol. 81, No. 1, 31-37. https://psycnet.apa.org/record/2012-11011-003

[23] H. Hikichi, J. Aida, T. Tsuboya, K. Kondo, I. Kawachi. (2016). Can community social cohesion prevent posttraumatic stress disorder in the aftermath of a disaster? A natural experiment from the 2011 Tohoku earthquake and tsunami, American Journal of Epidemiology, Vol. 183, No. 10, 902-910.https://academic.oup.com/aje/article/183/10/9 $02 / 2195708$ ?login=true

[24] J. Elliott, C. R. Gale, S. Parsons, D. Kuh, HALCyon Study Team. (2014). Neighbourhood cohesion and mental wellbeing among older adults: a mixed methods approach, Social Science \& Medicine, Vol. 107, 44-51. https://www.sciencedirect.com/science/article/pii/S027795 3614001312

[25] R. Rios, L. S. Aiken, A. J. Zautra. (2012). Neighborhood contexts and the mediating role of neighborhood social cohesion on health and psychological distress among Hispanic and non-Hispanic residents, Annals of Behavioral Medicine, Vol. 43, No. 1, 50-61. https://academic.oup.com /abm/article/43/1/50/4563936?login=true

[26] J. Kim. (2017). The role of social cohesion in addressing the impact of COVID-19 on mental health within marginalized communities, Local Development \& Society, Vol. 1, No. 2 , 205-216. https://www.tandfonline.com/doi/full/10.1080/26 883597.2020 .1829985

[27] H. Abu Suhaiban, L. R. Grasser, A. Javanbakht. (2019). Mental health of refugees and torture survivors: A critical review of prevalence, predictors, and integrated care, International Journal of Environmental Research and Public Health, Vol. 16, No. 13, 2309-2323. https://www.mdpi.co $\mathrm{m} / 1660-4601 / 16 / 13 / 2309$

[28] M. Bogic, A. Njoku, S. Priebe. (2015). Long-term mental health of war-refugees: A systematic literature review, BMC International Health and Human Rights, Vol. 15, No. 1, 1-41.https://bmcinthealthhumrights.biomedcentral.com/ articles/10.1186/s12914-015-0064-9

[29] M. Hynie. (2018). The social determinants of refugee mental health in the post-migration context: A critical review, The Canadian Journal of Psychiatry, Vol. 63, No. 5, 297-303. https://journals.sagepub.com/doi/full/10.1177/07 06743717746666

[30] J. G. Júnior, J. P. de Sales, M. M. Moreira, W. R. Pinheiro, C. K T. Lima, M. L. R. Neto. (2020). A crisis within the crisis: The mental health situation of refugees in the world during the 2019 coronavirus (2019-nCoV) outbreak, Psychiatry Research, Vol. 288, 113000. https://www.ncbi.nlm.nih.gov/pmc/articles/PMC7156944/

[31] S. Rees, J. Fisher. (2020). COVID-19 and the Mental Health of People From Refugee Backgrounds, International Journal of Health Services, Vol. 50, No. 4, 415-417. https://journals.sagepub.com/doi/full/10.1177/0020731420 942475

[32] W. Sieffien, S. Law, L. Andermann. (2021). Immigrant and refugee mental health during the COVID-19 pandemic: Additional key considerations, Canadian Family Physician, 1-3. https://www.cfp.ca/news/2020/06/23/06-23-1

[33] H. D. Vonen, M. L. Olsen, S. S. Eriksen, S. S., Jervelund, T.
A. Eikemo. (2021). Refugee camps and COVID-19: Can we prevent a humanitarian crisis?, Scandinavian Journal of Public Health, 49: 27-28. https://journals.sagepub.com/doi /full/10.1177/1403494820934952

[34] H. Comtesse, S. Powell, A. Soldo, M. Hagl, R. Rosner. (2019). Long-term psychological distress of Bosnian war survivors: An 11-year follow-up of former displaced persons, returnees, and stayers, BMC psychiatry, Vol. 19, No. 1, 1-10.https://bmcpsychiatry.biomedcentral.com/artic les/10.1186/s12888-018-1996-0

[35] X. Chen, B. Stanton, J. Gong, X. Fang, X. Li. (2009). Personal Social Capital Scale: An instrument for health and behavioral research, Health education research, Vol. 24, No. 2, 306-317. https://academic.oup.com/her/article/24/2/306/ $573546 ? \operatorname{login}=$ true

[36] Y. Cai. (2017). Bonding, bridging, and linking: Photovoice for resilience through social capital, Natural Hazards, Vol. 88, No. 2, 1169-1195.https://link.springer.com/article/10.1 007/s11069-017-2913-4

[37] J. T. Terrion. (2006). Building social capital in vulnerable families: Success markers of a school-based intervention program, Youth \& Society, Vol. 38, No. 2, 155-176. https://journals.sagepub.com/doi/abs/10.1177/0044118X05 282765

[38] J. Kahne, B. Chi, E. Middaugh. (2006). Building social capital for civic and political engagement: The potential of high-school civics courses, Canadian Journal of Education, Vol. 29, No. 2, 387-409. https://www.jstor.org/stable/2005 4169

[39] N. E. Brune, T. Bossert. (2009). Building social capital in post-conflict communities: Evidence from Nicaragua, Social Science \& Medicine, Vol. 68, No. 5, 885-893. https://www.sciencedirect.com/science/article/abs/pii/S027 7953608006680

[40] C. Roberts. (2013). Building social capital through leadership development, Journal of Leadership Education, Vol. 12, No. 1, 54-73.https://journalofleadershiped.org/wp -content/uploads/2019/02/12_1_Roberts.pdf

[41] C. Burnett. (2006). Building social capital through an 'Active community club', International Review for the Sociology of Sport, Vol. 41, No. 3-4, 283-294. https://journals.sagepub.com/doi/abs/10.1177/1012690207 078381

[42] W. J. Peachey, A. Cohen, J. Borland, A. Lyras. (2013). Building social capital: Examining the impact of Street Soccer USA on its volunteers, International Review for the Sociology of Sport, Vol. 48, No. 1, 20-37. https://journals.sagepub.com/doi/abs/10.1177/1012690211 432068

[43] J. Skinner, D. H. Zakus, J. Cowell. (2008). Development through sport: Building social capital in disadvantaged communities, Sport Management Review, Vol. 11, No. 3, 253-275. https://www.tandfonline.com/doi/abs/10.1016/S1 $441-3523 \% 2808 \% 2970112-8$

[44] E. Bassett, S. Moore. (2013). Social capital and depressive symptoms: The association of psychosocial and network dimensions of social capital with depressive symptoms in Montreal, Canada. Social Science \& Medicine, Vol. 86, 96-102. https://www.sciencedirect.com/science/article/abs/ pii/S0277953613001585 
[45] F. Verduin, G. E. Smid, T. R. Wind, W. F. Scholte. (2014). In search of links between social capital, mental health and sociotherapy: A longitudinal study in Rwanda. Social Science \& Medicine, Vol. 121, 1-9.https://www.sciencedir ect.com/science/article/abs/pii/S0277953614006212

[46] E. Landstedt, Y. B. Almquist, M. Eriksson, A. Hammarström. (2016). Disentangling the directions of associations between structural social capital and mental health: Longitudinal analyses of gender, civic engagement and depressive symptoms. Social Science \& Medicine, Vol. 163, 135-143. https://www.sciencedirect.com/science/artic le/abs/pii/S0277953616303501

[47] A. M. Almedom. (2005). Social capital and mental health: An interdisciplinary review of primary evidence. Social Science \& Medicine, Vol. 61, No. 5, 943-964. https://www.sciencedirect.com/science/article/abs/pii/S027 7953605000249
[48] C. J. Riumallo-Herl, I. Kawachi, M. Avendano. (2014). Social capital, mental health and biomarkers in Chile: assessing the effects of social capital in a middle-income country. Social Science \& Medicine, Vol. 105, 47-58. https://www.sciencedirect.com/science/article/abs/pii/S027 7953613007107

[49] E. Villalonga-Olives, T. R. Wind, I. Kawachi (2018). Social capital interventions in public health: A systematic review, Social Science \& Medicine, Vol. 212, 203-218. https://www.sciencedirect.com/science/article/abs/pii/S027 7953618303794

[50] E. C. Flores, D. C. Fuhr, A. M. Bayer, A. G. Lescano, N. Thorogood, V. Simms (2018). Mental health impact of social capital interventions: A systematic review, Social Psychiatry and Psychiatric Epidemiology, Vol. 53, No. 2, 107-119. https://link.springer.com/article/10.1007/s00127$017-1469-7$ 